\title{
Effect of salinity on the survival and growth of mud crabling, Scylla serrata
}

\author{
M.Y. MIA ${ }^{1}$, and M.M.R. Shah \\ Bangladesh Fisheries Research Institute, Brackishwater Station, Paikgacha, Khulna-9280, Bangladesh \\ ${ }^{1}$ Department of Environmental Science \& Resource Management, Mawlana Bhashani Science \& Technology \\ University, Santosh, Tangail-1902, Bangladesh
}

\begin{abstract}
An experiment was conducted for a period of eight weeks under laboratory conditions to determine the effect of different salinity levels on the survival and growth of crablings of mud crab, Scylla serrata. The different salinity levels tested were: 5 ppt, 10 ppt, 15 ppt, 20 ppt and 25 ppt. The differences in growth increment in terms of body weight $(B W)$ were significant $(p<0.05)$ among different salinity treatments. The specific growth rate (SGR\%/day) values of 2.67, 2.85, 4.07, 4.39 and 4.46 at 5 ppt, $10 \mathrm{ppt}, 15 \mathrm{ppt}, 20 \mathrm{ppt}$ and $25 \mathrm{ppt}$, respectively were found significant $(\mathrm{p}<0.05)$. The survival rates of crablings were found to be the highest $(47.67 \%)$ at 25 ppt and lowest $(10 \%)$ at $5 \mathrm{ppt}(\mathrm{p}<0.05)$. The results indicated that increase of salinity from 5 to $25 \mathrm{ppt}$ had significant effect on the survival and growth of mud crablings.
\end{abstract}

Key words: Mud crabling, salinity, specific growth rate, survival rate

\section{Introduction}

Salinity is an important environmental variable for estuarine organisms, as it has many important physiological and ecological effects (Christiansen \& Costlow 1975, Anger 1991, Minagawa 1992). It is also an important environmental factor for estuarine crabs as it may affect growth through its influence on food intake, conversion efficiency and activity, which are important components of the bioenergetic budget. It is commonly known that mud crab, Scylla serrata is a marine/estuarine species and can not survive without saline water. Based on this, culture of this commercially important crab species has been undertaken in saline water environment. Some studies have been made on larval rearing and seed production of mud crab giving special emphasis on salinity (Marichamy \& Rajapackiam 1992, Zainoddin 1992). Marichamy and Rajapackiam (1992) studied on larval rearing and seed production of the mud crab, S. serrata with a salinity around 35 ppt. Zainoddin (1992), conducted a study on rearing of the larvae of the mud crab, S. serrata in Malaysia with a salinity ranging from 29 to $32 \mathrm{ppt}$. Several papers deal with the salinity tolerance, effect of salinities on larval development of different species of crabs (Ong \& Costlow 1970, Mia \& Shokita 1997, Hsueh 1998). As far as it is known no studies have been made for the optimization of salinity requirements of mud crablings in Bangladesh. With this view, the present study was conducted to evaluate the effect of salinity on the survival and growth of mud crablings of $S$. serrata.

\section{Materials and Methods}

Salinity tolerance of mud crablings, S. serrata was studied for eight weeks under laboratory conditions at Brackishwater Station, Bangladesh Fisheries Research Institute, Piakgacha, Khulna. Crablings were collected from tidal water in the Sankha River of Paikgacha region under Khulna district, Bangladesh. Salinity of the river water was about $15 \mathrm{ppt}$ and collected crablings were temporarily kept in same salinity for a day.

Different test saline waters $(5,10,15,20$ and 25 ppt) were prepared by mixing brine with tap water. The tap water was stored in plastic containers and aerated continuously at ambient room temperature $\left(30^{\circ} \mathrm{C}\right)$. All salinities were checked with a hand held refractometer to the nearest 1 ppt. In total 15 fiber glass aquaria $(50 \mathrm{~L})$ were used for this experiment. Each aquarium was filled up with 30 liter saline water and few pieces of gravel and stone for shelter of test specimens.

Ten crablings (carapace length: $1.43 \pm 0.21 \mathrm{~cm}$; carapace width: $2.06 \pm 0.29 \mathrm{~cm}$ and body weight: $1.67 \pm 0.75 \mathrm{~g}$ ) were released into each of five aquarium with five different salinity treatments viz., T1 (5 ppt), T2 (10 ppt), T3 (15 ppt), T4 (20 ppt) and T5 (25 ppt) and the experiment was replicated thrice. The crablings were fed daily with slaughterhouse waste @ 5\% of the total biomass. 
Tested saline water in each aquarium was replenished (app. 60-80\%) daily with new supplies of saline water. At the time of replenishment, observations and counts were done for survival of crablings. Growth performance in respect of body weight (BW) of crablings was recorded at weekly interval. Growth gained by the crablings was expressed in Specific Growth Rate (SGR) by the following formula:

Specific Growth Rate (SGR\%/day) $=\left(\log _{\mathrm{e}} \mathrm{L}_{2}-\right.$ $\left.\log _{e} L_{1}\right) \times 100 /\left(T_{2}-T_{1}\right)$; where, $L_{2}=$ Final weight of crabling (g), $L_{1}=$ Initial weight of crabling $(g), T_{2}-$ $\mathrm{T}_{1}=$ Duration of the experiment (day).

\section{Results and Discussion}

The survival rates of mud crablings after eight weeks with variations in different salinity levels are shown in Table 1. At the end of the experiment, survival rates were $10,13.33,21.40,39.83$ and $47.67 \%$, respectively in $\mathrm{T} 1, \mathrm{~T} 2, \mathrm{~T} 3, \mathrm{~T} 4$ and $\mathrm{T} 5$. The highest survival of $47.67 \%$ was found in 25 ppt and the lowest of $10 \%$ in 5 ppt. Survival rate in $25 \mathrm{ppt}(47.67 \%)$ and $20 \mathrm{ppt}(39.83 \%)$ were significantly $(p<0.05)$ higher than that of 5,10 and $15 \mathrm{ppt}$; though no significant $(\mathrm{p}>0.05)$ difference on survival rate was found among 5,10 and 15 ppt. Survival rate of $39.83 \%$ and $46.67 \%$ respectively, in 20 and 25 ppt also showed no significant $(p>0.05)$ difference. High mortality was observed with the continuation of the experiment. Mortality due to cannibalism was a common problem and this could have affected the results. Generally, newly moulted crablings are attacked by others which resulted in death. Mortality of crablings due to cannibalism has been widely reported (Iversen 1986, Ryther \& Bardech 1974, Costlow 1967). Khan \& Alam (1992) stated that mud crabs, S. serrata were distributed over a wide range of salinity, from 2 ppt to oceanic waters, from the coast to the interior brackish waters and are essentially euryhaline, but die beyond $70 \mathrm{ppt}$. Salinity tolerances and requirements for zoeal stages and juvenile crabs are not same. Hill (1974) reported that the first stage zoeae of $S$. serrata are not tolerant to high temperature (above $25^{\circ} \mathrm{C}$ ) or low salinity (below $17.5 \mathrm{ppt}$ ). The salinity required for egg incubation was $32 \mathrm{ppt}$ (Christopher 1992). It indicates that salinity requirements for crab's survival and reproduction are not same. They survive and grow in lower salinity but are not able to reproduce.
Prinpanapong and Youngwanichsaed (1992) cultured mud crabs separately in ponds for two months, where range of salinity during two months period was 10-20 ppt (avg. $15 \mathrm{ppt}$ ) in pond 1 and $10-23 \mathrm{ppt}$ (avg.16 ppt) in pond 2. The survival rate was $60.92 \%$ in pond 1 and $51.45 \%$ in pond 2 . On the whole, the survival rate was $57.63 \%$. From the above discussion, it is clear that mud crablings survive and grow within low salinity up to $23 \mathrm{ppt}$. Kathirvel (1980) reared juveniles $(1.7-2.9 \mathrm{~cm})$ for 80 days at salinity ranges from $22-30$ ppt and survival rates was $85 \%$. In the present study, highest survival of $47.67 \%$ with the highest salinity of $25 \mathrm{ppt}$ indicates that higher salinity has a positive influence on survival of mud crablings. Kathirvel (1980) also found that juveniles of $S$. serrata could survive at 4 ppt with acclimation. The lower survival rates (12.5-50\%) were recorded at $8-10 \mathrm{ppt}$ without acclimation and at 51ppt with acclimation (12.5\% survival) (Nair et al. 1974). From their results and the results of the present study indicating the euryhaline nature of mud crab species.

The changes in body weight (BW) of mud crablings reared in five different salinities for eight weeks are shown in Fig. 1. Significant difference $(p<0.05)$ was observed from the changes of BW of mud crablings during the experimental period among the treatments which indicated that salinity levels of $5 \mathrm{ppt}$ to $25 \mathrm{ppt}$ had an effect on the changes of their body weight.

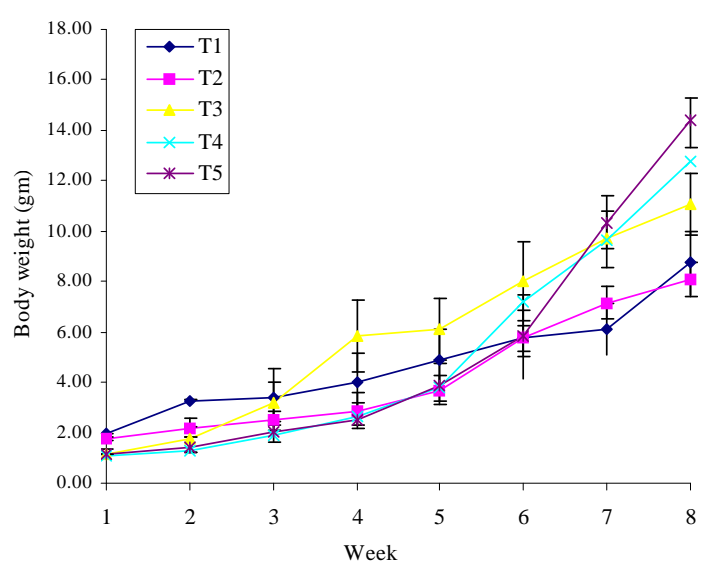

Fig. 1. Effect of salinity on the growth of body weight (g) of mud crablings, $S$. serrata. 
The specific growth rates (SGR\%/day) are shown in Table 2. SGR by weight recorded in mud crablings were $2.67,2.85,4.07,4.39$ and 4.46 $\% /$ day respectively, in $5,10,15,20$ and 25 ppt. However, among the treatments significantly $(p<0.05)$ highest SGR $(4.46 \% / d a y)$ was found in $25 \mathrm{ppt}$ and the lowest $(2.67 \% /$ day $)$ in 5 ppt. Present results indicate that higher salinity has a positive relation with growth. Experimental culture of mud crab, S. serrata was done for a growout period of 115 days by Samarasinghe et al. (1992) where salinity varied from 22-32 ppt and SGR was recorded as $1.67 \%$ /day. In their study, SGR was small as adult crabs do not mould frequently like juvenile crabs. SGR was also recorded to be $3.33 \% /$ day by Mia et al (2003) in a seven weeks laboratory trial using $25 \mathrm{ppt}$ saline water. Their result is similar to the present study. From the present results of SGR, it may be concluded that higher salinity appears to be good for growth of the mud crabling.
Hence, it could be concluded that mud crab is a euryhaline species but specific saline water is essential for its larval metamorphosis and breeding. Since the salinity of estuary and sea water is not fixed but related with some factors like temperature, current, turbidity etc, so further research is needed using more higher saline water above $25 \mathrm{ppt}$ to at least $45 \mathrm{ppt}$. In the present study, survival rate is lower than other result (Kathirvel 1980) though it is similar with the results (12.5\%) of Nair et al. (1974).

In the present study, cannibalism occurred within the crablings as newly moulted crablings came within the reach of other crabs. This happened due to the experiments being carried in a closed water body like fiber glass aquarium. This might be one of the factors affecting the lower survival of mud crablings in this study.

Table 1. Mean survival of mud crablings, S. serrata in different weeks under different levels of salinities.

\begin{tabular}{c|c|c|c|c|c|c|c|c}
\hline \multirow{2}{*}{ Treatment } & \multicolumn{10}{c}{ Survival (\%) } \\
\cline { 2 - 9 } & $1^{\text {st }}$ week & $2^{\text {nd }}$ week & $3^{\text {rd }}$ week & $4^{\text {th }}$ week & $5^{\text {th }}$ week & $6^{\text {th }}$ week & $7^{\text {th }}$ week & $8^{\text {th }}$ week \\
\hline T1 (5\%) & 98.33 & 90.00 & 67.67 & 43.33 & 30.00 & 23.33 & 16.67 & $10.00^{\text {b }}$ \\
T2 (10\%) & 96.67 & 60.00 & 30.00 & 30.00 & 26.67 & 23.33 & 20.00 & $13.33^{\text {b }}$ \\
T3 (15\%) & 100 & 93.33 & 86.67 & 73.33 & 56.67 & 30.00 & 26.66 & $21.40^{\text {b }}$ \\
T4 (20\%) & 100 & 93.33 & 83.33 & 80.00 & 73.33 & 62.00 & 54.17 & $39.83^{\text {a }}$ \\
T5 (25\%) & 100 & 96.67 & 93.33 & 88.33 & 80.00 & 65.00 & 61.67 & $47.67^{\mathrm{a}}$ \\
\hline
\end{tabular}

*Different letters are significantly $(p<0.05)$ different when compared with DMRT

Table 2. Specific growth rates of mud crablings, S. serrata reared in different levels of saline water.

\begin{tabular}{c|c|c|c}
\hline Treatments & Initial weight (g) & Final weight (g) & $\begin{array}{c}\text { Specific growth rates (SGR) } \\
\% / \text { day }\end{array}$ \\
\hline T1 (5 ppt) & $1.95 \pm 0.07$ & $8.75 \pm 1.50$ & $2.67^{\mathrm{b}}$ \\
T2 (10 ppt) & $1.76 \pm 0.06$ & $8.07 \pm 0.66$ & $2.85^{\mathrm{b}}$ \\
T3 (15 ppt) & $1.13 \pm 0.52$ & $11.09 \pm 1.24$ & $4.07^{\mathrm{a}}$ \\
T4 (20 ppt) & $1.10 \pm 0.50$ & $12.79 \pm 1.53$ & $4.39^{\mathrm{a}}$ \\
T5 (25 ppt) & $1.18 \pm 0.19$ & $14.41 \pm 0.88$ & $4.46^{\mathrm{a}}$ \\
\hline
\end{tabular}

*Different letters are significantly $(p<0.05)$ different when compared with DMRT 


\section{References}

Anger, K. 1991. Effects of temperature and salinity on the larval development of the Chinese mitten crab Eriocheir sinensis (Decapoda: Grapsidae). Marine Ecol. Prog. Ser. 72:103-110.

Christiansen, M.E. \& Costlow, J.D. JR. 1975. The effect of salinity and cyclic temperature on larval development of the mud crab Rhithropanopeus harrisii (Brachyura: Xanthidae) reared in the laboratory. Marine Biol. 32:215-221.

Christopher, L. 1992. A brief overview of the ecology and fisheries of the mud crab, Scylla serrata, in Queensland. In: The Mud Crab. A report on the seminar convened in Surat Thani, Thailand, pp. 6570 .

Costlow, J.D. 1967. The effect of salinity and temperature on survival and metamorphosis of megalops of blue crabs, Callinectes sapidus. Helgolander. Wiss. Meereunters. 15:84-97.

Hill, B.J. 1974. Salinity and temperature tolerance of zoea of the portunid crab, Scylla serrata. Marine Biol. 25(1):21-24.

Hsueh, P.W. 1998. Salinity tolerance of hard stage Pinnotheres bidentatus (Decapoda: Brachyura: Pinnotheridae). Crustacean Res. 27:82-87.

Iversen, E.S. 1986. Farming in the edge of the sea. Fishing News Books, UK. 301 pp.

Kathirvel, M. 1980. Abundance of portunid crab seeds in Cochin backwater. In: Proc. Symp. On Coastal Aqua, Mar. Biol. Assn. Ind., Abs. No. 94.

Khan, M.G. \& Alam, M.F. 1992. The Mud Crab (Scylla serrata) fishery and its Bio-Economics in Bangladesh. In: The Mud Crab. A report on the seminar convened in Surat Thani, Thailand, pp. 2940.

Marichamy, R. \& Rajapackiam, S. 1992. Experiments on larval rearing and seed production of the mud crab, Scylla serrata. In: The Mud Crab. A report on the seminar convened in Surat Thani, Thailand, pp. 135-141.

Mia, M.Y. \& Shokita, S., 1997. Optimal salinity required for the larval development of two grapsid crabs, Helice leachi Hess and $H$. formosensis Rathbun. Crustacean Res. 26:70-74.

Mia, M.Y., Rheman, S. \& Alam, M.J. 2003. Comparative study of two feeds of mud crab, Scylla serrata. University j. zool. Rajshahi Univ. 22:125-130

Minagawa, M. 1992. Effects of salinity on survival, feeding and development of larvae of the red frog crab Ranina ranina. Nippon Suisan Gakkaishi. 58(10):1855-1860.

Nair. R.V., Bensam, P. \& Marichamy, R. 1974.
Possibilty of marine fish culture in the salt pan area at Tuticorin. Ind. J. Fish., 21(1):120-126.

Ong, K. S., \& Costlow, J. D. JR. 1970. The effect of salinity and temperature on the larval development of stone crab, Menippe mercenaria (Say), reared in the laboratory. Chesapeake Sci. 11:16-29.

Prinpanapong, S. \& Youngwanichsaed, T. 1992. Rearing of mud crab (Scylla serrata). In: The Mud Crab. A report on the seminar convened in Surat Thani, Thailand, pp. 191-194.

Ryther, J. \& Bardech, J. 1968. The status and potential of aquaculture, particularly invertebrate and algae culture. U.S. Dept. Comm. pp. 177-767, p. 261.

Samarasinghe, R.P., Fernando, D.Y. \& de Silva, O.S. S.C. 1992. Pond culture of mud crab in Srilanka. In: The mud crab, C. A. Angel (ed.). pp. 161-164. Proceeding of the seminar on mud crab in Surat Thani, Thailand, 5-8 November, 1991. Bay of Bengal, Madras.

Zainoddin, B.J. 1992. Preliminary studies on rearing the larvae of the mud crab (Scylla serrata) in Malaysia. In: The Mud Crab. A report on the seminar convened in Surat Thani, Thailand, pp. 143-147. 